\title{
Postsurgical adhesion formation score pitfalls in endometriosis surgery
}

\author{
Ospan A. Mynbaev ${ }^{1,2} \cdot$ Amirkhan K. Baimaganbetov $^{1} \cdot$ Michael Stark $^{1,3}$
}

Received: 31 May 2021 / Accepted: 13 June 2021 / Published online: 21 June 2021

(c) The Author(s), under exclusive licence to Springer-Verlag GmbH Germany, part of Springer Nature 2021, corrected publication 2021

\section{Dear Editor,}

We read with great attention the well-designed randomized article by Kramer et al. which was published in your journal [1]. This study reports the advantages of the adhesion barrier 4 DryField $®$ PH in patients following endometriosis surgery. The severity and extent of adhesions, as well as the incidence of the adhesion formation based on the number of affected sites, were significantly reduced after the application of the adhesion barrier when compared to the control group. It is well-known that the main concern in endometriosis surgery is the extension and severity of endometriosis involving the uterine wall, ovaries, and surrounding area, cul-de-sac bladder, ureter, sigmoid (colon), and the pelvic wall with deeply located nodes [2]. The postsurgical adhesion parameters (incidence, extension, and severity) after surgery depend on the extension and the severity of the endometriosis. The authors presented endometriosis scores in two classification systems (Table 1): the rASRM [3] and ENZIAN [4]. Both did not show significant differences among the groups, although the ENZIAN score demonstrated higher percentages of uterine adenomyosis (FA) and deeply infiltrated bladder endometriosis (FB) in the control group (respectively $22 \%$ vs $35 \%$ and $13 \%$ vs $26 \%$ ). Subsequently, surgical procedures in these locations might result in more adhesions which could increase the incidence, extension, and severity of the condition. The amounts of the barrier components varied

Ospan A. Mynbaev

ospanmynbaev@gmail.com

1 Department of Traumatology, Orthopedics and Oncology, Khoja Akhmet Yassawi International Kazakh-Turkish University, Bekzat Sattarkhanov Avenue, 29, Turkistan, Kazakhstan

2 Moscow Institute of Physics and Technology, National Research University, Dolgoprudny, Moscow region, Russia

3 New Europen Surgical Academy, Berlin, Germany widely with the range of powder (1-5 g) and saline solution $(2-20 \mathrm{ml})$ showing differences in their application areas after surgery. In parallel, the amount of saline ranged highly $(5-200 \mathrm{ml})$, showing that the endometriosis surgical procedures were performed with varied extensions. Therefore, post-surgical adhesions occurring in many sites in one patient with severely traumatic surgery could produce misleading results. We believe that the patients were randomized blindly using the MS Excel RAND and this misleading situation certainly was not the intention of the authors. It might show the number of patients with and without post-surgical adhesions and also adhesion scores depending on the severely traumatic surgical procedures with excision of the deep endometrial nodes. The study design of postsurgical adhesion formation should take into account the character of the surgical pathology which might produce possible methodological shortcomings in the adhesion score since there are significantly different adhesion formation abilities of visceral and parietal tissues [5], depending on single or combined traumatic surgical procedures during the same operation [6].

\section{References}

1. Krämer B, Andress J, Neis F, Hoffmann S, Brucker S, Kommoss S, Höller A (2021) Adhesion prevention after endometriosis surgery - results of a randomized, controlled clinical trial with second-look laparoscopy. Langenbecks Arch Surg. https://doi.org/ 10.1007/s00423-021-02193-x

2. Koninckx PR, Ussia A, Adamyan L, Wattiez A, Donnez J (2012) Deep endometriosis: definition, diagnosis, and treatment. Fertil Steril 98(3):564-571. https://doi.org/10.1016/j.fertnstert.2012.07. 1061

3. The American Fertility Society (1988) The American Fertility Society classifications of adnexal adhesions, distal tubal occlusion, tubal occlusion secondary to tubal ligation, tubal pregnancies, Mullerian anomalies and intrauterine adhesions. Fertil Steril 49(6):944-955

4. Tuttlies F, Keckstein J, Ulrich U, Possover M, Schweppe KW, Wustlich M, Buchweitz O, Greb R, Kandolf O, Mangold R, 
Masetti W, Neis K, Rauter G, Reeka N, Richter O, Schindler AE, Sillem M, Terruhn V, Tinneberg HR (2005) ENZIAN-Score, eine Klassifikation der tief infiltrierenden Endometriose [ENZIANscore, a classification of deep infiltrating endometriosis]. Zentralbl Gynakol 127(5):275-81. German. https://doi.org/10. 1055/s-2005-836904

5. Mynbaev OA, Eliseeva MY, Kalzhanov ZR, Lyutova L, Pismensky SV, Tinelli A, Malvasi A, Kosmas IP (2013) Surgical trauma and $\mathrm{CO} 2$-insufflation impact on adhesion formation in parietal and visceral peritoneal lesions. Int J Clin Exp Med 6(3):153-165

6. Kulakov VI, Adamian LV, Mynbaev OA (1998) Postoperative adhesions: etiology, pathogenesis and prevention. M: Medicine [Rus]

Publisher's note Springer Nature remains neutral with regard to jurisdictional claims in published maps and institutional affiliations. 